Sabine Blahudka $\cdot$ Michael Türkay

\title{
A population study of the shrimp Crangon allmanni in the German Bight
}

Received: 21 February 2001 / Accepted: 15 May 2002 / Published online: 16 July 2002

C) Springer-Verlag and AWI 2002

\begin{abstract}
The only reproducing population of Crangon allmanni within the German Bight is in the Helgoland Trench (HTR), a depression of more than $50 \mathrm{~m}$ depth south of Helgoland. In coastal and shallower offshore waters the shrimp is much rarer and is recorded in higher numbers only in early spring when the water is still cold. The life cycle of the HTR population lasts for about 1.5 years maximum. Recruitment takes place in summer, and these recruits form the reproducing population of the next year. The shrimps are sensitive to environmental stress and are therefore good indicators of environmental changes.
\end{abstract}

Keywords Crangon allmanni - German bight . Population structure $\cdot$ Reproduction

\section{Introduction}

Crangon allmanni is, after the common Crangon crangon, the second most abundant species of the genus in the German Bight. Both species are distinguished by the morphology of the sixth abdominal segment, which bears a deep longitudinal groove and two parallel carinae in $C$. allmanni. Furthermore the colour is different. $C$. crangon has an overall grey coloration, whilst $C$. allmanni is reddish (a dull grey-red, with darker chromophores). In trawl catches the latter are easily recognisable through their colour and are thus termed "Roter Granat" ("red shrimp") by commercial fishermen in Germany. This term, however, is also used for the much rarer Pandalus montagui Leach 1814, which appears on rare occasions in coastal waters during the cold season.

Communicated by H.-D. Franke

S. Blahudka · M. Türkay $(\bullet)$

Forschungsinstitut Senckenberg, Senckenberganlage 25, 60325 Frankfurt am Main, Germany e-mail: mtuerkay@sng.uni-frankfurt.de

Tel.: +49-69-7542240
In contrast to the commercial $C$. crangon, little is known about the biology of $C$. allmanni. The most comprehensive study, including morphology and distribution, was conducted by Allen (1960) in Northumberland waters. There are some further studies from other parts of the North Sea; the western part and Dutch waters by Creutzberg and van Leeuwen (1980), and by Jayamanne (1995) from the Estuary and the Firth of Forth. Wehrtmann (1989) worked on the occurrence and development of larvae in the German Bight, Criales (1985) and Criales and Anger (1986) studied larval development in the laboratory.

Concerning population biology, Allen (1960) proposed a seasonal migration to shallow coastal waters in October and back offshore in late spring (April/May). In contrast, Creutzberg and van Leeuwen (1980) could not detect any migratory movement in the south-western North Sea. They observed a rapid decline in abundance in summer, which they attributed to high mortality rather than migration.

Regular long-term trawl sampling by the "Forschungsinstitut Senckenberg" in the German Bight revealed that there was a constant high abundance of the shrimp only in the Helgoländer Tiefe Rinne (HTR), which probably comprised the sole population in the German Bight (see Caspers 1939). In other parts of the German Bight the numbers in the catches were low, and most were caught during winter and spring cruises.

The HTR is a relatively deep depression south-west of the island of Helgoland $\left(54^{\circ} 8.6^{\prime} \mathrm{N}, 7^{\circ} 53.4^{\prime} \mathrm{E}\right)$. Its average depth is about $50 \mathrm{~m}$, the maximum depth $59 \mathrm{~m}$. Since other parts of the German Bight are about $35 \mathrm{~m}$ or less, the HTR differs in its hydrographic conditions; bottom temperature and salinity are more influenced by oceanic conditions and oscillate less than in the coastal areas. Therefore the HTR represents an isolated relatively deep area within the German Bight. Sediments differ as well: whereas sandy and muddy bottoms characterise most of the German Bight, the HTR has secondary hard grounds, consisting of molluscan shells (Hertweck 1988). 
Table 1 Numbers of specimens of Crangon allmanni from the Helgoland Trench (HTR) examined for this study

\begin{tabular}{|c|c|c|c|c|c|c|c|c|c|c|c|c|c|}
\hline Year & Jan & Feb & Mar & Apr & May & Jun & Jul & Aug & Sep & Oct & Nov & Dec & Total \\
\hline 1985 & & 5 & & & 118 & & 11 & 246 & 25 & 856 & 416 & & 1,677 \\
\hline 1986 & 28 & & & 419 & & 262 & & 125 & 59 & & 19 & 59 & 971 \\
\hline 1987 & 304 & 76 & & 41 & 671 & 192 & 73 & 40 & 2 & & & 20 & 1,419 \\
\hline 1988 & & & 223 & & 14 & 19 & 75 & & 15 & & 363 & & 709 \\
\hline 1992 & & & & & & & & & 791 & & & & 791 \\
\hline Total & 332 & 81 & 223 & 460 & 803 & 473 & 159 & 411 & 892 & 856 & 798 & 79 & 5,567 \\
\hline
\end{tabular}

Studies on the faunal composition and occurrence of species in the HTR have been carried out by Caspers (1939), Berberich (1989) and Becker (1995).

In the present paper, the population of $C$. allmanni and its size-structure in the HTR are studied for the first time to gain some idea about its life cycle in this part of the North Sea. To examine the structure of this population, samples from 1985 to 1988 (Table 1) were analysed by sex, fecundity and morphometry.

In addition, samples from Jade Bay, a shallow estuarine area in the German Bight, were studied for comparison with the HTR regarding population composition and migratory movements. In this onshore area both Crangon species occur, and it was of special interest to compare abundance, and to see whether there were any seasonal differences indicative of migration.

\section{Methods}

Sampling

As part of a qualitative screening of the epibenthic fauna of the German Bight, regular sampling was conducted by RV Senckenberg. Cruises to the HTR and to Jade Bay took place monthly (as far as weather conditions allowed) from 1982 (HTR) and 1978 (Jade Bay), respectively, until 1992.

For all catches a $2 \mathrm{~m}$ beam trawl with a tickler chain and mesh size of $1 \times 1 \mathrm{~cm}$ in the cod end was used. Each haul covered a distance of about 1 nautical mile at 2 knots, which equals a sea bed surface of about $3,740 \mathrm{~m}^{2}$.

Beam trawls are efficient for qualitative sampling of epibenthic fauna - they are used in shrimp and plaice fisheries. However, they are less appropriate for quantitative surveys. The mesh size of $1 \times 1 \mathrm{~cm}$ limits the size of the animals caught, and small specimens such as juveniles will only be caught incidentally if the meshes become clogged by larger individuals.

From each catch a random subsample of 10 or 18 litres from the total catch of the HTR, and a 1 litre crangonid sample from Jade Bay, were taken. Specimens were fixed in formalin (4\%) diluted with fresh water, and then transferred to alcohol (70\%).

\section{Analysis}

For this study all animals collected in the HTR from 1985 until 1988 (and one reference sample from 1992) were analysed, because this period included the sampling nearest to regular monthly intervals. The study period in Jade Bay was extended (from 1978 to 1991) to examine the longer-term relations of the two crangonid species.

All shrimps were classified as males, females (ovigerous and non-ovigerous) and juveniles. The juveniles consisted of all animals of less than $5 \mathrm{~mm}$ carapace length. Determination of sex was not possible in some shrimps of this group.
Fig. 1 Carapace of Crangon allmanni with points for the measurement of length $(C L)$

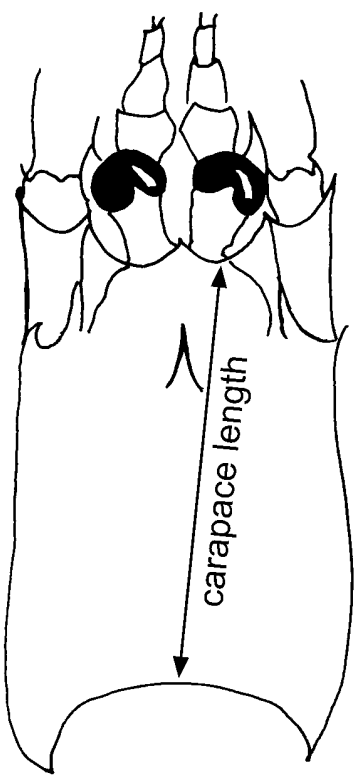

To distinguish males and females, the first and second pleopods were examined using a binocular microscope. As described by Allen (1960), males bear an appendix masculina above the base of the inner edge of the second pleopod whereas females do not. The endopodite of the first pleopod differs in males and females: it is rather elongated in females and short and blade-shaped in males.

Carapace length (CL) was measured from the posterior of the orbit to the posterior median margin of the carapace (Fig. 1) because these were the most reliable points. In addition, the total length of one sample of shrimps was measured $(n=138)$ and a linear relationship of carapace length to total length determined. The calculated ratio was 4.66 in females and 4.77 in males $(r=0.93$ in males, $r=0.96$ in females). Measurements were carried out with an ocular micrometer to the nearest $0.2 \mathrm{~mm}$. Changes in length due to preservation were not taken into account but it was assumed that shrinkage had terminated after so many years. The measurements of total length thus specify minimum values.

\section{Results}

\section{Distribution of C. allmanni in the German Bight}

The distribution map (Fig. 2) shows all stations in the southern North Sea where C. allmanni was caught during summer cruises (July-September). In spite of local and temporal variability, the abundance was low in summer at all these stations except in the HTR. 
Fig. 2 Map showing the southern North Sea stations sampled with RV Senckenberg in the summer months (July-September). Filled triangle: more than 20 specimens of Crangon allmanni per station; empty triangle: fewer than 20 specimens of C. allmanni per station; $r e$ versed empty triangle: no $C$. allmanni in the catches

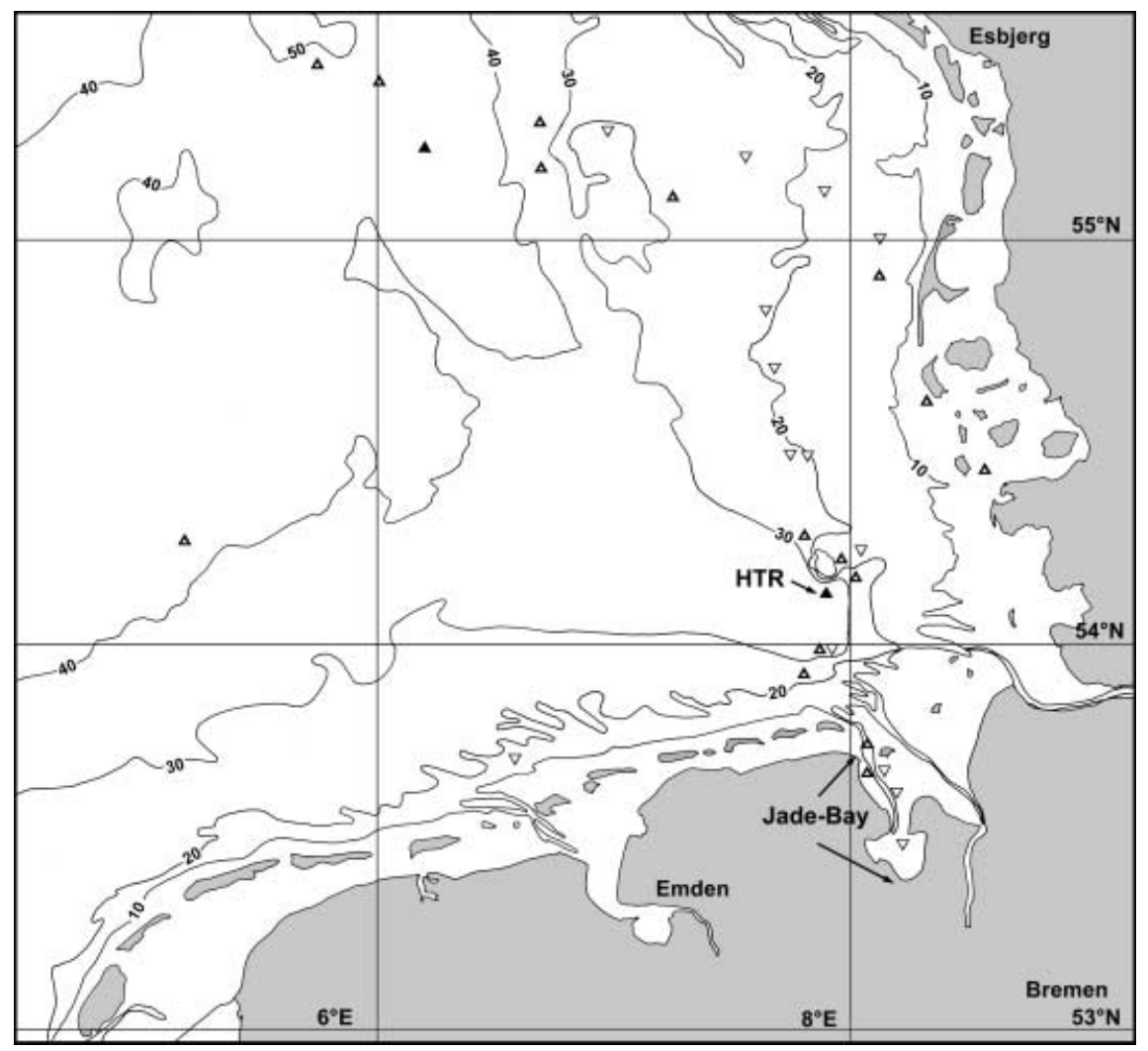

Population of the HTR

A total of 5,567 animals was studied (Table 1): the lengths of $140(2.5 \%)$ specimens could not be determined because the carapace was broken.

\section{Length composition}

The largest animal measured $11.4 \mathrm{~mm}$ carapace length (CL), the smallest $2.4 \mathrm{~mm}$. The largest male $(9.6 \mathrm{~mm}$ CL) was caught in November 1987 at, the largest females $(11.4 \mathrm{~mm})$ were found in several springtime samples.

The monthly mean CL of the population, averaged for the period 1985-1988, followed an annual cycle (Fig. 3). It was at its minimum in October, and in the following months until January there was a clear increase in CL (by about $1 \mathrm{~mm}$ ). From January to July there was no apparent growth, except minor oscillations that were not taken into account. After the main breeding season in April-June and the following moult there was some apparent growth in July-August. The mean CL then suddenly decreased by more than $1 \mathrm{~mm}$ from August to October and increased again afterwards.

In summer the population mainly consists of nonovigerous females of 6.2-8.8 mm CL. In October there is a sudden change in size-distribution pattern: the larger shrimps of the summer have disappeared. There is a new group of smaller animals (5-7.8 mm CL), including a large number of males. This group probably comprises

\section{$C L$} [mm]

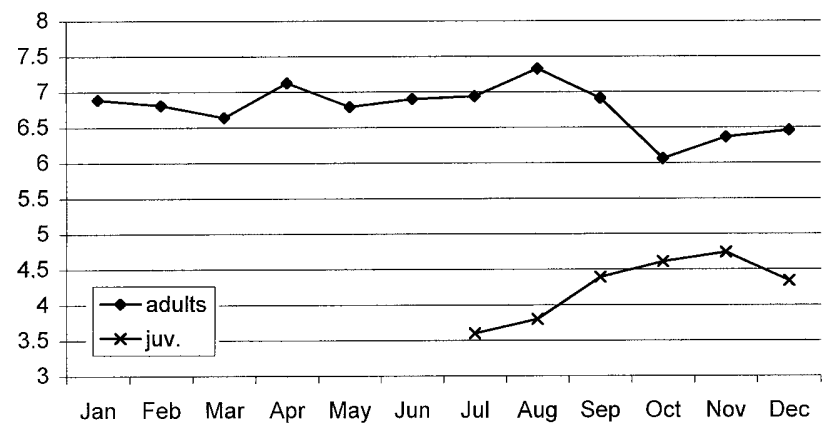

Fig. 3 Mean carapace length $(C L)$ of all shrimps caught in the Helgoland Trench $(H T R)$ as a function of the annual cycle

the 0-group of the year, replacing the 1-group. As well as this 0-group there is a small number of large females in the catches, which may represent the remnants of the 1group, breeding for a second year and remaining in the catches until June/July of the following year.

The new 0-group shows faster growth of females than of males during the following months. The number of males in the catches is very low in spring and summer.

Referring to males only, the minimum mean CL occurred in September, which was earlier than in females. In the following months there was also some increment. Autumn thus seems to be the crucial time of the year for the structure of the population. 


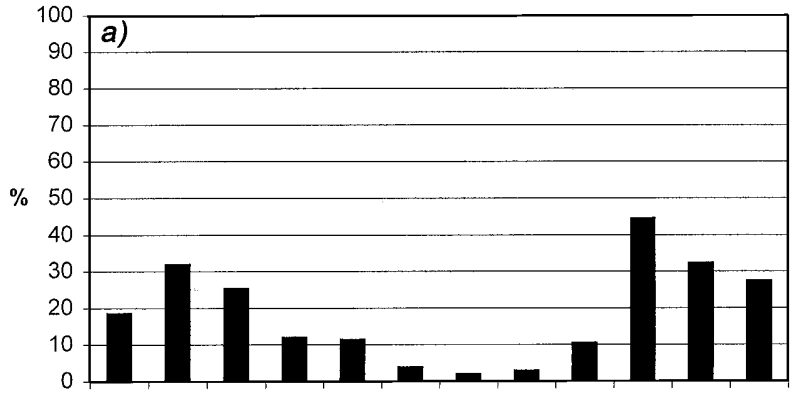

Jan Feb Mar Apr May Jun Jul Aug Sep Oct Nov Dec

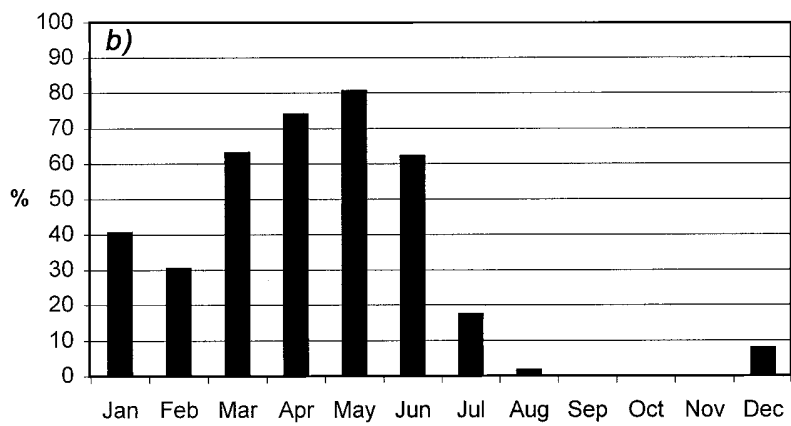

Fig. 4 Seasonal patterns of relative abundance of different types of shrimps in the HTR catches. Percentages of total monthly shrimp numbers (1985-1988): a males, b ovigerous females

Fig. 5 Size distribution of Crangon allmanni from four large HTR catches taken at different times of the annual cycle. The selected examples most clearly illustrate the trend which was obvious in all years: a 30 January1987; b: 15 June 1987; c: 25 August 1985; d: 24 October 1985
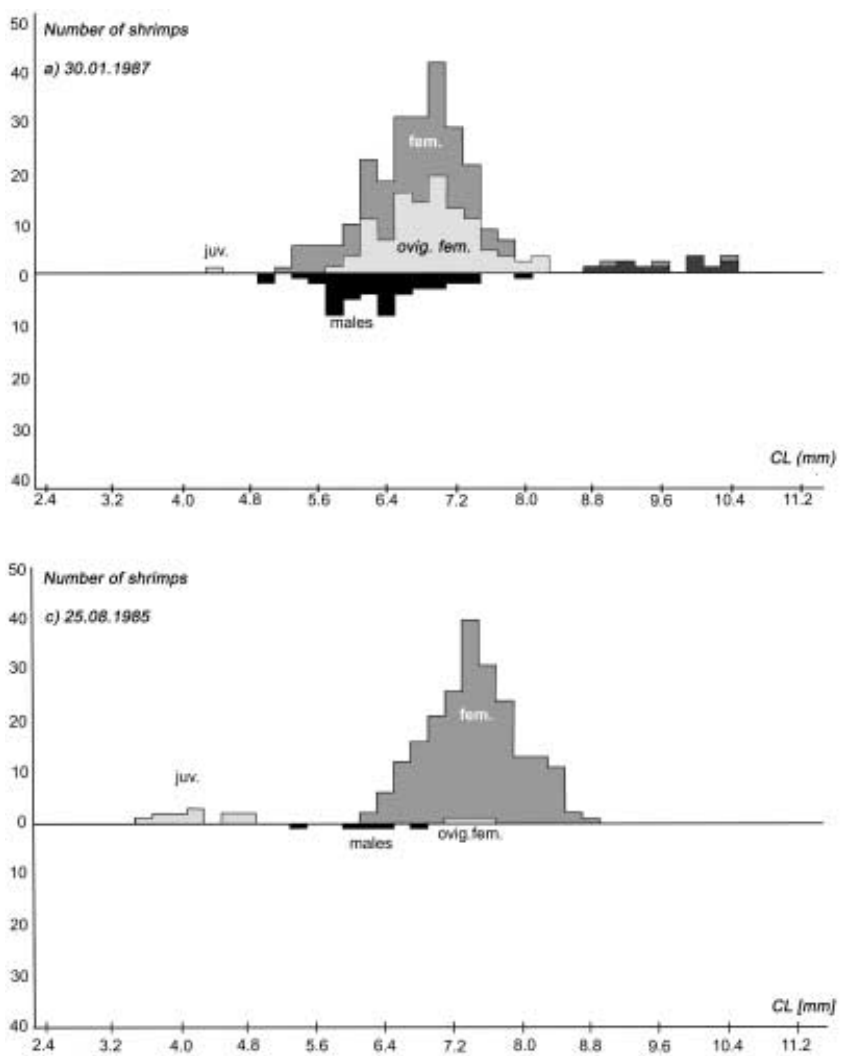

The mean CL of juveniles increased strongly from their first appearance in the catches in July until November. Therefore the main recruitment seems to take place from September to November.

There was a significant $(t>p=0.01)$ difference in size between males and females throughout the year (Student's $t$-test) except in autumn and early winter, when males and females had the same size distribution.

\section{Reproductive seasonality}

Reproductive seasonality was analysed according to the occurrence of ovigerous females. Results were confirmed by the appearance of juveniles in the catches.

Ovigerous females occurred from December until August, and were lacking in the samples between September and November. In December, July and August the proportion of ovigerous females was low, with the maximum number occurring from March to June (Fig. 4). The smallest berried females measured $5 \mathrm{~mm} \mathrm{CL}$, caught in May and June 1987.

The ratio of male to female shrimps in the catches ranged from about 0.8 in winter to less than 0.1 in summer and was always below 1 . As to the size distribution, the large females of about 7.6-8.0 mm CL, which still form a peak in late August, have virtually disappeared by late October, when the population peak is formed by much smaller (i.e. 5.6-6.0 mm CL) females. The reference sample of 29 September 1992 shows that this decrease of large females has already taken place in September and might be a common autumn effect. This is il-
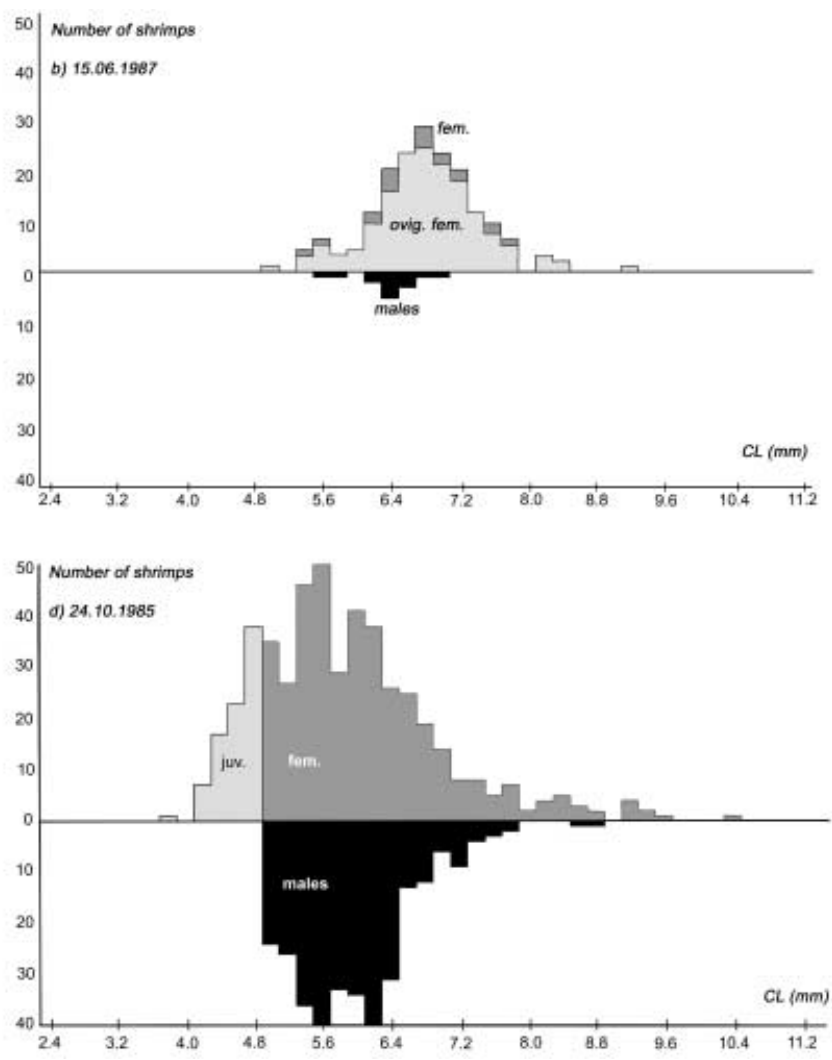


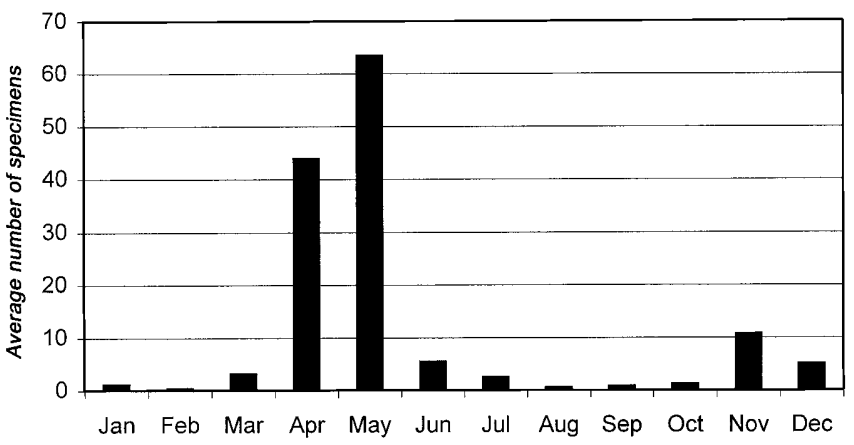

Fig. 6 Average monthly numbers of Crangon allmanni caught in Jade Bay, during the period 1978-1991

lustrated by examples of larger samples taken in the period studied (Fig. 5).

September seems to be the most important month for recruitment, as composition of sex and size both changed at about this time in all years.

\section{C. allmanni in Jade Bay}

The total number of shrimps caught from 1978 to 1991 was 1,471 . The largest numbers were recorded in winter and spring - in April and May the average number in the catches was comparatively high, whereas it was low in summer (Fig. 6). However, a comparison of the total numbers of $C$. crangon and $C$. allmanni caught in Jade Bay makes clear that the latter plays a minor role in coastal waters, on average accounting for only $3.8 \%$ of all crangonids in the catches. The ratio of $C$. crangon to $C$. allmanni shows that a higher percentage of $C$. allmanni was regularly caught in spring (April-May), mostly after the minimum water temperature (Fig. 7).
There were, however, some specimens of $C$. allmanni in the autumn and winter samples as well. For this presentation the ratios during the years 1986-1989 were selected, because over this period the catches were mostly taken at the same station in Jade Bay.

The length composition of shrimps extended from $5 \mathrm{~mm}$ to $10.2 \mathrm{~mm}$ CL (two specimens). The largest male was $8.2 \mathrm{~mm}$ CL. Ovigerous females occurred from December to June. There were no juveniles in the catches. Other than the lack of large and juvenile shrimps, there was no significant difference in size from the HTR samples, nor was there any difference in sex ratio.

\section{Discussion}

\section{Distribution of C. allmanni in the German Bight}

There might be an inherent tendency that $C$. allmanni avoids shallow areas in summer, preferring deeper areas and rather oceanic conditions. In winter Atlantic water reaches further south than in summer (Goedecke et al. 1967). In addition there is a strong circulation intensity at this time of the year in southern shallow areas which is influenced by meteorological variability (cf. Heyer et al. 1994; Pohlmann and Puls 1994).

Regarding the higher abundance in winter and spring there might be a link between the circulation patterns and distribution of water masses and the occurrence of C. allmanni in coastal areas of the German Bight.

\section{Population of the HTR}

Because of the methods of sampling, the number of shrimps in the catches could not necessarily be regarded
Fig. 7 Crangon allmanni as a percentage of all crangonid specimens caught in Jade Bay during 1986-1989, superposed on the water temperature curve of Minsener Oog, outer Jade Bay

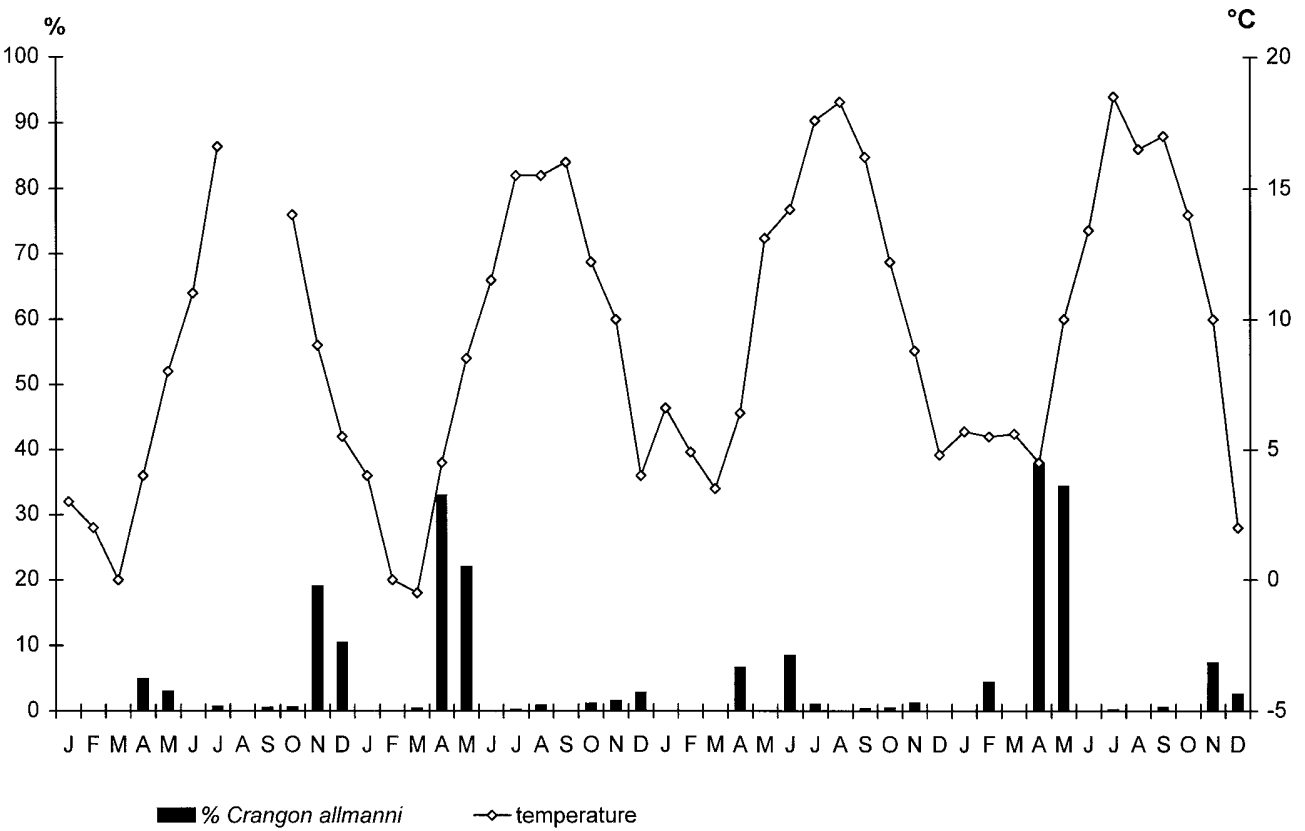


as representative of the numbers in the environment, but because sampling was random the samples may reflect population composition. Within each year studied the distribution of size classes, and occurrence of ovigerous females, males and even juveniles, were fully comparable.

The results of the study allow us to describe the life cycle of $C$. allmanni in the HTR. Juvenile shrimps appear in the catches in summer, with a CL of 3-5 $\mathrm{mm}$. These are the new recruits of the year, which is confirmed by data on egg and larval development given by Criales (1985) and Wehrtmann (1989). Egg development is said to take 10-12 weeks in winter and 5-6 weeks in summer (Allen 1960). In the case of the HTR, ovigerous females occur in late December, indicating that first larvae will be released by late April and May. In 1985 Wehrtmann found larvae of $C$. allmanni near Helgoland from May to September, with a distinct peak in June (63\% of the total larvae). Stage-I larvae occurred until the end of August, being at a peak by the end of June. Older-stage larvae and juveniles were caught from late June to early September. Larvae of the last stage (VIII) were first obtained at the end of July. This developmental time agrees with the laboratory results of Criales (1985) of 6-7 weeks at $12^{\circ} \mathrm{C}$. Water temperature (at $1 \mathrm{~m}$ depth) in the HTR area is below $12^{\circ} \mathrm{C}$ in April, May and June. If the larvae are released about late April and May, there will be a $8-10$ week period to the first occurrence of juveniles in the catches in July. Due to the mesh size, the trawl did not catch such small shrimps, so it cannot be exactly determined when newly metamorphosed juveniles appeared. The larvae released by ovigerous females in June will presumably have completed their metamorphosis by September.

As ovigerous females occur over a long period, a prolonged breeding season must be assumed, covering several months and probably including two spawning events and recruitments. The ratio of juveniles to adults is very high in September, when recruitment takes place.

The disappearance of most shrimps in summer, and their replacement by smaller ones in autumn, might be explained by mortality of the 1-group.

Considering the distribution of size classes in the HTR and the proposed life-cycle, it seems reasonable to assume an average life span of $1-1.5$ years as was proposed by Creutzberg and van Leeuwen (1980) for Dutch waters. As a consequence of this model, the abundance of shrimps decreases in summer due to mortality. This mortality might also explain why there is a low number of shrimps in the catches in Jade Bay and at most stations of the German Bight in summer.

Concerning protandric hermaphroditism, which is known from C. crangon (Tiews 1954, 1970; Boddeke 1989), there is no clear evidence for $C$. allmanni. The small number of males in the catches, and the lack of large males and their decrease during the year, might suggest sex change during development. However, due to the prolonged breeding season and presumably several spawning events, the occurrence of ovigerous females did not account for such a phenomenon. Assuming a 1-1.5 year life span of the shrimps, sex change would have to take place within a few months after maturation. If this was linked to the decrease of males in summer, males would disappear within a few months anyway as do most of the females, and would not be able to breed. The number of large females, on the other hand, seems to be too small to include males which have undergone sex reversal. Anatomical and histological analysis of the gonads is necessary in order to clarify this question.

\section{C. allmanni in Jade Bay}

There was evidently no recruitment of the shrimps in Jade Bay since there were no juveniles in the catches, and the total numbers of shrimps were low over most of the year. There are no records of larvae from Jade Bay (Trepte 1991; Wolf 1991; Hesemann 1995), and in any case abundance is low in the eastern parts of the North Sea (Lindley 1987) except in the neighbourhood of Helgoland (Wehrtmann 1989). The occurrence of shrimps in Jade Bay is probably caused by water-influx-related transport, and specimens may originate from the HTR, and be carried along by currents in southerly directions. Especially in spring, prevailing south-easterly winds push surface waters in northward directions, while there is a southward influx of deep cold water from northern areas (König and Schrumm 1994). In winter, therefore, oceanic water reaches far south and could also be a means of transportation (Heyer et al. 1994). This might explain the maximum numbers of specimens caught in winter and spring. The shrimps may also come from more western parts of the open North Sea by means of the circulation of the German Bight, which mainly follows the German coastline anticlockwise.

The disappearance of shrimps in summer might be due to a high mortality rate, as seen in the HTR, which might be further triggered by the faster and higher increases in water temperature in coastal waters (Fig. 8).

\section{General discussion}

The results clearly demonstrate that the only reproducing population of $C$. allmanni in the German Bight is to be found in the HTR, where both adult specimens and juveniles were caught in large numbers and the complete life-cycle is apparent. It is, however, impossible to say to what extent the population is self-sustaining, and what is the proportion of recruitment from other parts of the North Sea. Furthermore it is unclear to what extent larvae from the HTR are transported to different places within and outside the German Bight by the current system, as proposed by Wehrtmann (1989).

Temperature measurements do not give clear evidence of differing seasonal characteristics in the HTR as compared with Jade Bay except that in the coastal area temperature rises and declines earlier, its minimum being 
${ }^{\circ} \mathrm{C}$
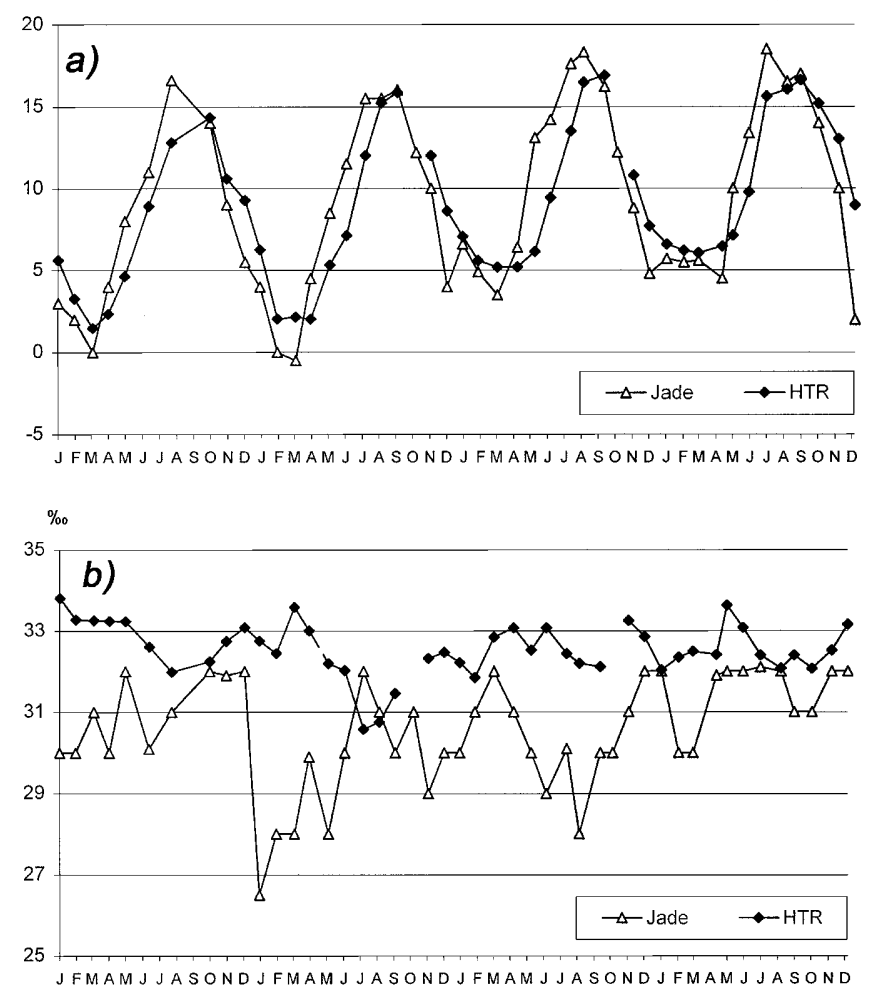

Fig. 8 Hydrographic conditions of HTR and Jade Bay during the period 1986-1989; a temperature, b salinity

lower and its maximum higher (by about $3-4^{\circ} \mathrm{C}$ ) than in the HTR (Fig. 8a). This suggests more stable environmental conditions in the HTR.

In the HTR, salinity stays at a constant high level throughout the year, reflecting more stable oceanic conditions. In contrast, the salinity in coastal waters is lower and highly variable (Fig. 8b). Data taken from offshore areas of the open North Sea, in which C. allmanni is quite abundant, exhibit a low variability in bottom water salinity throughout the year (Goedecke et al. 1967; Bundesamt für Seeschiffahrt und Hydrographie 1996). This suggests that the main environmental factor required by $C$. allmanni in order to form a stable population is constant high water salinity at an oceanic level.

This might also explain the striking differences between the population in the HTR and that described by Allen (1960) off the Northumberland coast. Although ovigerous females appear at the same time and there is a prolonged breeding season, recruitment starts earlier in the HTR and the highest numbers of ovigerous females are found in spring instead of in July, as reported by Allen (1960) for Northumberland waters. This indicates a faster rate of development in the German Bight. As the first juveniles of the new generation (0-group) appear in summer - instead of November as in Northumberland first breeding may take place in the first year in the HTR. Furthermore there is only one annual population peak, which disappears in summer followed by repopulation in autumn by the new recruits, whereas Allen (1960) observed two population peaks, breeding in the second year, and an average life span of 2-2.5 years. In addition there is no evidence of migratory movements from the population structure in the HTR. Growth, development and the life cycle obviously take much more time in Northumberland waters, but with shrimps reaching approximately the same maximum length and length at first breeding as in the HTR.

An important reason for these differences might be hydrographic conditions. Temperature $\left(5-11^{\circ} \mathrm{C}\right)$ and salinity $(34 \% 0)$ of Northumberland waters are much more constant (Allen 1960) than they are in the HTR, and this may result in a longer life span. The influence of these hydrographic conditions, especially of temperature, on the growth rate (e.g. moulting and intermoults) of shrimps has been widely acknowledged (see Hartnoll 1982).

The sensitivity of $C$. allmanni to environmental stress can be further seen by the fact that $C$. crangon from trawl samples can be kept alive on board quite easily, while most $C$. allmanni die within a short period if not immediately transferred to aerated tanks containing lowtemperature sea water. It might thus be concluded that $C$. allmanni prefers constant oceanic conditions with relatively cool, oxygen-rich water. These preferences make the species more suitable for environmental monitoring, especially in areas where an increase in sea-water temperature is observed, resulting in changes in the hydrographic regime. The regular monitoring of the $C$. allmanni population in the HTR, and the species' occurrence in shallow coastal waters may thus provide valuable data for describing the environmental status of the German Bight ecosystem.

Acknowledgements Thanks are due first of all to our late colleague Dr. Jürgen Dörjes and his assistant Christa Rensing (both Senckenberg Institute, Wilhelmshaven) for their efforts in collecting and preserving the material for this study at regular monthly intervals over the years whenever one of us was not on board. We also thank captain and crew of RV Senckenberg for their careful handling of ship and gear, which largely contributed to the success of our work. Temperature and salinity data were received from Prof. B.W. Flemming and Dr. A. Bartholomä (both Senckenberg Institute, Wilhelmshaven) and Dr. F. Nast (German Oceanographic Data Centre, DOD, Hamburg), which we also gratefully acknowledge. Special thanks are due to Dr. R. Hartnoll (Port Erin Marine Laboratory, Isle of Man, UK) for critically reading and commenting on an earlier version and for streamlining our English.

\section{References}

Allen JA (1960) On the biology of Crangon allmanni Kinahan in Northumberland waters. J Mar Biol Assoc UK 39:481-508

Becker A (1995) Untersuchungen zur Decapodenfauna der Helgoländer Tiefen Rinne, Jahreszyklen 1991 und 1992. Diploma thesis, University of Frankfurt, Germany

Berberich D (1989) Vergleichende Untersuchungen zur Artenzusammensetzung, Abundanz und Biomasse des Makrozoobenthos der Helgoländer Tiefen Rinne von 1936/37 und 1988/89. Diploma thesis, Technische Hochschule Darmstadt

Boddeke R (1989) Management of the brown shrimp Crangon crangon stock in Dutch coastal waters. In: Caddy JF (ed) Marine invertebrate fisheries, Wiley, New York, pp 35-62 
Bundesamt für Seeschiffahrt und Hydrographie (1996) Nordseeboje II, Wassertemperatur und Salzgehalt. http://www.bsh.de/ Meeresumweltschutz/MARNET/nsb2_oze_1996.html

Caspers H (1939) Die Bodenfauna der Helgoländer Tiefen Rinne. Helgol Wiss Meeresunters 2:1-112

Creutzberg F, Leeuwen F van (1980) The life cycle of Crangon allmanni Kinahan in the southern North Sea.(ICES CM 1980/L: 71) Biological Oceanography Committee

Criales MM (1985) Untersuchungen zur Larvalentwicklung von Crangon crangon L. und Crangon allmanni Kinahan (Decapoda, Natantia, Caridea). Doctoral dissertation, University of Kiel, Germany

Criales MM, Anger K (1986) Experimental studies on the larval development of the shrimps Crangon crangon and Crangon allmanni. Helgol Meeresunters 40:241-265

Goedecke E, Smed J, Tomczak G (1967) Monatskarten des Salzgehaltes der Nordsee, dargestellt für verschiedene Tiefenhorizonte. Dtsch Hydrogr Z B9:1-13

Hartnoll RG (1982) Growth. In: Abele GM (ed) The biology of Crustacea. 2. Embryology, morphology and genetics. Academic Press, New York, pp 111-196

Hertweck C (1988) Zonierung der Faziesbereiche in der Helgoländer Tiefen Rinne. Bochum Geol Geotech Arb 29:71-73

Hesemann H (1995) Tageszeitliche Feinauflösung des Auftretens von Decapodenlarven im Plankton der Innenjade. Diploma thesis, University of Frankfurt, Germany

Heyer K, Engel M, Brockmann UH, Rick H-J, Dürselen C-D, Hühnerfuss H, Kammann U, Steinhart H, Kienz W, Krause M, Karbe L, Faubel A, Rieger S (1994) Local studies in the German Bight during winter/spring 1988/89. In: Sünderman J (ed) Circulation and contaminant fluxes in the North Sea. Springer. Berlin Heidelberg New York, pp 190-249
Jayamanne SC (1995) Population dynamics, biology and ecology of the caridean shrimps; Crangon crangon Linnaeus, Crangon allmanni Kinahan and Pandalus montagui Leach in the Estuary and Firth of Forth, Scotland. PhD thesis, Stirling University, UK

König P, Schrumm C (1994) Ozeanographie. In: BMFT (eds) Prozesse im Schadstoffkreislauf Meer-Atmosphäre. Abschlussbericht des BMFT-Projektes, Hamburg, pp 45-47

Lindley JA (1987) Continuous plankton records: the geographical distribution and seasonal cycles of decapod crustacean larvae and pelagic post-larvae in the north-eastern Atlantic Ocean and the North Sea, 1981-83. J Mar Biol Assoc UK 67:145167

Pohlmann T, Puls W (1994) Currents and transport in water. In: Sünderman J (ed) Circulation and contaminant fluxes in the North Sea. Springer, Berlin Heidelberg New York, pp 345-402

Tiews K (1954) Die biologischen Grundlagen der Büsumer Garnelenfischerei. Ber Dtsch Wiss Komm Meeresforsch 13: 235-270

Tiews K (1970) Synopsis of biological data on the common shrimp, Crangon crangon (Linnaeus, 1758). FAO Fish Rep 4: $1167-1224$

Trepte I (1991) Tages- und tideperiodische Variabilität im Auftreten von Decapodenlarven in der Jade (südliche Nordsee). Diploma thesis, University of Frankfurt, Germany

Wehrtmann I (1989) Seasonal occurrence and abundance of caridean shrimp larvae at Helgoland, German Bight. Helgol Meeresunters 43:87-112

Wolf F (1991) Untersuchungen zur Dekapodenfauna der Jade. Diploma thesis, University of Frankfurt, Germany 